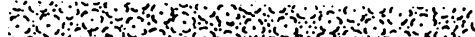 \\ (n)

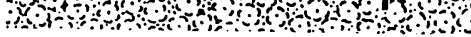 \\ 市販野菜及び果物中の総水銀定量法の改良並びに 総水銀の含有量調査
}

(平成 3 年 8 月 15 日受理)

$\begin{array}{lll}\text { 田 健* } & \text { 青木 喜 也* } & \text { 玉瀬喜久雄* } \\ \text { 兔本 文昭* } & \text { 岡山明子* } & \text { 大林 英 之* } \\ \text { 芋 生 眞子* } & \text { 佐々木美智子* } & \end{array}$

\section{Improved Method for Determination of Total Mercury and Its Application to Vegetables and Fruits in Markets}

\author{
Takeshi Tanaka, Yoshinari Aoki, Kikuo Tamase, Fumiaki Umoto, \\ Hideyuki OHBayashi, Masako IMOU and Michiko SASAKI
}

(Nara Prefectural Institute of Public Health: 57-6, Omori-cho, Nara 630, Japan)

To detect trace amounts of total mercury in vegetables and fruits, the wet digestion-cold vapor atomic absorption spectrometry method was improved.

The recoveries and the coefficients of variation for total mercury added to vegetables and fruits were $94 \sim 103 \%$ (average $99 \%$ ) and $2.0 \sim 11 \%$ (average 5.6\%) at $0.5 \mathrm{ppb}$, and $97 \sim 101 \%$ (average $99 \%$ ) and $2.8 \sim 6.3 \%$ (average $4.1 \%$ ) at $2.5 \mathrm{ppb}$. The detection limit was $0.1 \mathrm{ppb}$ in the samples.

The improved method was adapted to the determination of trace amounts of total mercury in 27 kinds of vegetables and fruits (81 samples) collected from markets in Nara Prefecture. The obtained mean amounts of total mercury were less than $0.1 \mathrm{ppb}$ for 10 species, $0.1 \sim 1.0 \mathrm{ppb}$ for 12 species and $1.0 \sim 2.4 \mathrm{ppb}$ for 5 species. These values are lower by $1 \sim 2$ orders of magnitude than those reported by other researchers.

(Received August 15, 1991)

Key words：総水銀 total mercury；湿式分解 wet digestion；野菜 vegetable；果物 fruit；還元 気化原子吸光法 cold vapor atomic absorption spectrometry

\section{緒言}

水銀は, 自然界に広く分布し，微量ながら野菜，果物 にも含まれているが，魚介類に比べて微量であり，昭和 48 年に水銀農薬が使用禁止になった以後は測定データ の報告例は見あたらない，現在，野菜，果物に水銀農薬 は使用されていないが，使用禁止以前に使用していた水 銀農薬による影響が今日においても存在する可能性が考 えられる. また, 水銀のバックグラウンド值はよ゙のくら

* 奈良県衛生研究所： 7630 奈良市大森町 57-6
いであるかを，正確に把握することは食品衛生上有益で ある.

水銀の測定における試料の灰化処理には湿式分解

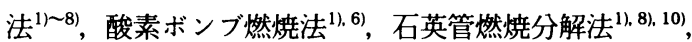
加熱気化一金アマルガム法1).61.11)などがあるが，一般的 には湿式分解法及び石英管燃焼分解法が，又，水銀検出 時における水銀の気化には還元気化法卓 6), 99及び加熱気 化法 ${ }^{1123,61,8)}$ が多く用いられている. このうち湿式分解 法は試料の多量を処理することができ，また，還元気化 法は試験溶液の全量を測定に用いることができることか 
ら，微量水銀の測定には，湿式分解 - 還元気化法が好ま しいと考える. 先に石英管燃焼分解一加熱気化法による 市販鮮魚の水銀について報告 ${ }^{1), 2)}$ したが, 野菜, 果物の水 銀は魚介類に比べて微量であることから，従来から行わ

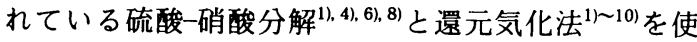
い，それらに若干の改良を加え，それを用い市販野菜及 び果物中の微量水銀を測定したので，その結果を報告す る.

\section{実験方法}

\section{1. 試薬及び標準液など}

(1) 試薬：硝酸，硫酸，過マンガン酸カリウム, 塩酸 ヒドロキシルアミンは和光純薬工業(株)製の有害金属用 または原子吸光用を，塩化第一スズはナカライテックス （株)製原子吸光用を用いた。

（2）水銀標準液：原子吸光用 $1000 \mu \mathrm{g} / \mathrm{ml}$ 標準液（和 光純薬工業(株)製）を希釈して $1 \mu \mathrm{g} / \mathrm{ml}$ 溶液をつくり, 標準原液とし，適宜，水で希釈して用いた。

（3）標隼混液：分液漏斗に水約 $50 \mathrm{ml}$, 硫酸 $10 \mathrm{ml}$ を 加え室温まで放冷後, $0.1 \mu \mathrm{g} / \mathrm{ml}$ の水銀標準溶液 $1 \mathrm{ml}$ を加えたすのを標隼混液とした。

(4) 5\%過マンガン酸カリウム溶液：過マンガン酸カ リウム $50 \mathrm{~g}$ をひうう取し, 水約 $800 \mathrm{ml}$ を加え加熱溶解 後, 水で $1 \mathrm{~L}$ とした.

(5) $10 \%$ 塩酸ヒドロキシルアミン溶液：塩酸ヒドロ キシルアミン $20 \mathrm{~g}$ をむう取し，水を約 $150 \mathrm{ml}$ 加えて 溶解し，さらに水を加えて $200 \mathrm{ml}$ とした。

(6) $20 \%$ 塩化第一スズ溶液：塩化第一スズ二水塩 30 $\mathrm{g}$ を水及び硫酸 $9 \mathrm{ml}$ で溶かして $150 \mathrm{ml}$ とした.

2. 装

（1）原子吸光装置：（株）島津製作所製 MERCURY ANALYZER UV-201

\section{3. 試料}

1991 年 1 月〜 2 月に奈良県内都市に流通している野 菜 21 種類 63 検体, 果物 6 種類 18 検体を試料とした.

\section{4. 測定方法}

（1）試料溶液の調製：野菜，果物の可食部をよく細断 し， $100 \mathrm{ml}$ 共栓付き三角フラスコに $20 \mathrm{~g}$ をひょう取し た. 直径約 $7 \mathrm{~mm}$ のガラスビーズ $2 \sim 3$ 個, 硝酸 $20 \mathrm{ml}$, 硫酸 $10 \mathrm{ml}$ を順次加え, ガラス製冷却管 (内径 $6.5 \mathrm{~mm}$, 長さ $60 \mathrm{~cm} ）$ を取り付け，ホットプレートの表面温度 $180^{\circ}$ で, 1 時間加熱した. 冷却管をはずした後, さらに, 2〜2.5 時間加熱し硝酸を気化させ, 濃縮分解を行った。 その後, 約 $10 \mathrm{ml}$ の水, $5 \%$ 過マンガン酸カリウム溶液 $10 \mathrm{ml}$ を順次加え, 約 $120^{\circ}$ で 20 分間加熱し試料溶液之 した.

（2）原子吸光測定：室温まで放冷した試料溶液に, $10 \%$ 塩酸ヒドロキシルアミン溶液 $8 \mathrm{ml}$ を加え, 過㮃の 過マンガン酸カリウムを分解した後, $100 \mathrm{ml}$ 分液漏斗 に約 $30 \mathrm{ml}$ の水で洗い移した。この溶液を水で約 $80 \mathrm{ml}$

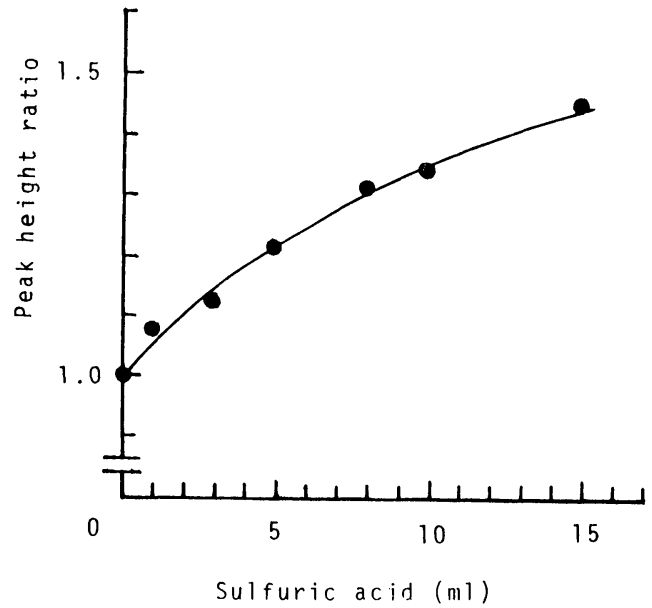

Fig. 1. Effect of sulfuric acid concentration on reduction of mercury

One $\mathrm{ml}$ of mercury solution $(0.1 \mu \mathrm{g} / \mathrm{ml})$ was added to each of sulfuric acid solution, which contains $0,1,3,5,8,10,15 \mathrm{ml}$ of sulfuric acid.

After being made up to $80 \mathrm{ml}$ with distilled water. $5 \mathrm{ml}$ of $20 \% \operatorname{tin}($ II $)$-chloride dihydrate solution was added and total mercury concentration was measured by cold vapor atomic absorption spectrometry.

とし, 手で激しく振り気泡を抜き，次いで，20\% 塩化第 一スズ溶液 $5 \mathrm{ml}$ を加え 5 分間振とう後, あらかじめ 2 $\mathrm{L} / \mathrm{min}$ で空気を吸引排気させている空気ポンプに分液 漏斗の先端を接続し空気流量がゼロになるまで数秒間お いた後, 分液漏斗の活栓を開き水銀蒸気を空気と共に吸 収セルに送り波長 $253.7 \mathrm{~nm}$ で測定した。

\section{結果及び考察}

\section{1. 水銀の還元気化条件の検討}

水銀の還元気化に影響する原因として溶液温度 ${ }^{13}$ 及び 使用する試薬量 ${ }^{13), 14)}$ が考えられる，そこで，使用する試 薬の影響を調べた。

（1）硫酸量：分液漏斗に水約 $50 \mathrm{ml}$ と硫酸を段階的 に 0 15 ml 加え, 室温になるまで放置した後, $0.1 \mu \mathrm{g} /$ $\mathrm{ml}$ の水銀標準溶液 $1 \mathrm{ml}$ 及び水を加え約 $80 \mathrm{ml}$ とした. 次ぎに $20 \%$ 塩化第一スズ溶液 $5 \mathrm{ml}$ を加え, 水銀の還元 気化に及ぼす硫酸量の影響を調べた。硫酸を添加しない 場合の原子吸光スペクトルのピーク高を 1 とし, それに 対し硫酸を加えた場合のピーク高の比を Fig. 1 に示し た. 硫酸量が $0 \sim 15 \mathrm{ml}$ の間では硫酸量の増加に伴い吸 光度む大きくなり, 硫酸量 $15 \mathrm{ml}$ では無添加の場合と比 較して約 1.5 倍の值を示した。 しかし, 硫酸量 $10 \mathrm{ml}$ で 測定感度屯十分なことから硫酸量は $10 \mathrm{ml}$ とした。 ま た，5\% 過マンガン酸カリウム溶液 $10 \mathrm{ml}$ と $10 \%$ 塩酸 


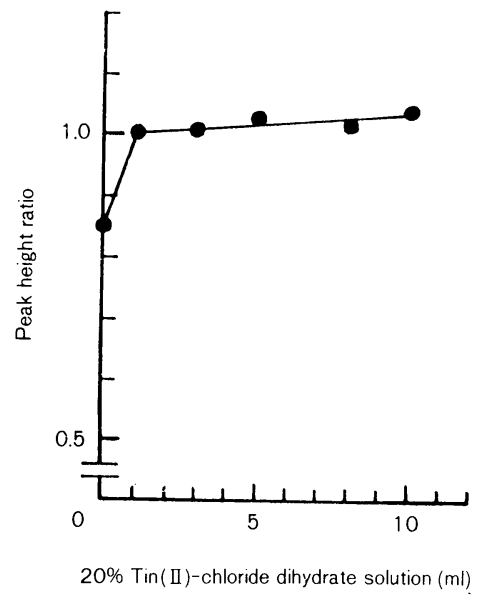

Fig. 2. Effect of $\operatorname{tin}($ II $)$-chloride dihydrate on reduction of mercury

Experimental conditions were same as Fig. 1, except for volume of sulfuric acid (10 $\mathrm{ml})$.

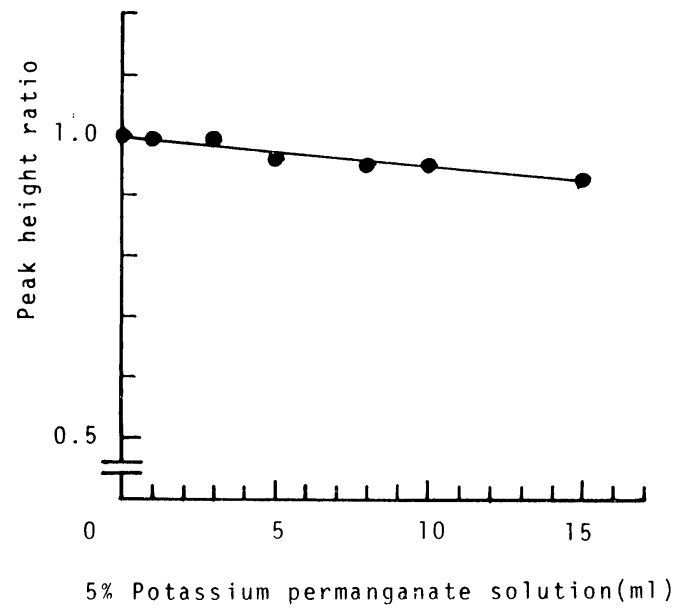

Fig. 3. Effect of potassium permanganate concentration on reduction of mercury

Experimental conditions were same as

Fig. 1, except for $10 \mathrm{ml}$ of sulfuric acid and $8 \mathrm{ml}$ of $10 \%$ hydroxylamine solution.

ヒドロキシルアミン溶液 $8 \mathrm{ml}$ を加えた場合も同様の傾 向を示し，その影響はなかった。

(2) 塩酸ヒドロキシルアミン量：標準混液に $10 \%$ 塩 酸七ドロキシルアミン溶液を段階的に $0 \sim 15 \mathrm{ml}$ 加え, 水を加えて, $80 \mathrm{ml}$ とし，20\% 塩化第一スズ溶液 $5 \mathrm{ml}$ を加えて，水銀の還元気化に及ぼす塩酸ヒドロキシルア ミン量の影響を調べた. 0〜 $15 \mathrm{ml}$ の範囲では, ピーク高 にほとんど変化は認められなかった。 そこで, 過マンガ ン酸カリウムの分解に十分な $8 \mathrm{ml}$ の塩酸ヒドロキシル

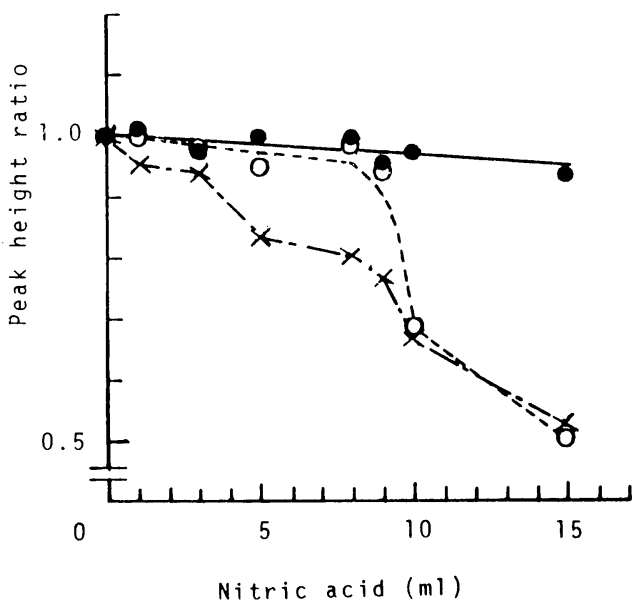

Fig. 4. Effect of nitric acid concentration on reduclion of mercury in the presence of hydroxylamine and potassium permanganate

- - nitric acid, $\times \cdots \times$ : nitric acid, $8 \mathrm{ml}$ of $10 \%$ hydroxylamine solution, -........ nitric acid, $10 \mathrm{ml}$ of $5 \%$ potassium permanganate solution and $8 \mathrm{ml}$ of $10 \%$ hydroxylamine solution.

Experimental conditions were same as Fig. 1, except for $10 \mathrm{ml}$ of sulfuric acid.

アミン溶液を加えることにした。

（3）塩化第一スズ量：標準混液に $20 \%$ 塩化第一スズ 溶液を段階的に $0 \sim 10 \mathrm{ml}$ 加え，水を加えて $80 \mathrm{ml}$ と し，水銀の還元気化に及ぼす塩化第一スズ量の影響を調 べた，その結果，Fig. 2 に示すとおり $20 \%$ 塩化第一ス ズ溶液 1〜10 $\mathrm{ml}$ の範囲ではピーク高は添加量の増加に 伴いわずかに高くなる傾向が見られるが， $5 \mathrm{ml}$ 前後で ほとんど変化がないことから $20 \%$ 塩化第一スズ溶液の 添加量は $5 \mathrm{ml}$ とした.

(4) 過マンガン酸カリウム量：標準混液に段階的に $5 \%$ 過マンガン酸カリウム溶液 0 15 ml 及び $10 \%$ 塩 酸ヒドロキシルアミン溶液 $8 \mathrm{ml}$ を加え, 水を加えて 80 $\mathrm{ml}$ とし, ついで $20 \%$ 塩化第一スズ溶液 $5 \mathrm{ml}$ を加えて, 過マンガン酸カリウム量の影響を調べた。その結果, Fig. 3 に示すとおり $5 \%$ 過マンガン酸カリウム溶液 0 $15 \mathrm{ml}$ の範囲ではピーク高は添加量の増加に伴いわずか に低くなる傾向が見られるが, $10 \mathrm{ml}$ 前後ではほとんど 変化がないことから 5\% 過マンガン酸カリウム溶液の 添加量は $10 \mathrm{ml}$ とした。

（5）硝酸量： 標準混液に硝酸を段階的に 0 15 ml 加 え，水を加えて $80 \mathrm{ml}$ とし，次いで $20 \%$ 塩化第一スズ 溶液 $5 \mathrm{ml}$ を加え硝酸量の影響を調查した。また，標準 混液に $10 \%$ 塩酸ヒドロキシルアミン溶液 $8 \mathrm{ml}$ を加え 
Table 1. Recovery of Total Mercury from Vegetables and Fruits*

\begin{tabular}{|c|c|c|c|c|c|c|}
\hline & $\begin{array}{l}\text { Sample weight } \\
(\mathrm{g})\end{array}$ & $\begin{array}{l}\mathrm{Hg} \text { added } \\
(\mathrm{ppb})\end{array}$ & $\begin{array}{l}\text { Hg mean } \\
\quad(\mathrm{ppb})\end{array}$ & $\begin{array}{l}\text { C.V. } \\
(\%)\end{array}$ & $\begin{array}{c}\text { Recovered } \\
(\mathrm{ppb})\end{array}$ & $\begin{array}{c}\text { Recovery ratio } \\
(\%)\end{array}$ \\
\hline \multirow[t]{3}{*}{ Chinese cabbage } & 20 & 0 & 0.28 & & & \\
\hline & 20 & 0.5 & 0.75 & 11 & 0.47 & 94 \\
\hline & 20 & 2.5 & 2.70 & 2.8 & 2.42 & 97 \\
\hline \multirow[t]{3}{*}{ Radish } & 20 & 0 & 0.06 & & & \\
\hline & 20 & 0.5 & 0.53 & 6.5 & 0.47 & 95 \\
\hline & 20 & 2.5 & 2.47 & 3.2 & 2.41 & 97 \\
\hline \multirow[t]{3}{*}{ Cucumber } & 20 & 0 & 0.02 & & & \\
\hline & 20 & 0.5 & 0.53 & 2.0 & 0.51 & 102 \\
\hline & 20 & 2.5 & 2.53 & 3.9 & 2.52 & 101 \\
\hline \multirow[t]{3}{*}{ Apple } & 20 & 0 & 0.17 & & & \\
\hline & 20 & 0.5 & 0.68 & 3.0 & 0.52 & 103 \\
\hline & 20 & 2.5 & 2.69 & 6.3 & 2.53 & 101 \\
\hline
\end{tabular}

*: Average of 3 trials

たものと，5\% 過マンガン酸カリウム溶液 $10 \mathrm{ml}$ 及び $10 \%$ 塩酸ヒドロキシルアミン溶液 $8 \mathrm{ml}$ を加えた場合と 比較した。 その結果を Fig. 4 に示した．硝酸のみでは 0 〜 $15 \mathrm{ml}$ の範囲では影響はみられなかった。しかし，塩 酸ヒドロキシルアミンを加えた場合には硝酸量と共に吸 光度の低下がみられた，又，過マンガン酸カリウムと塩 酸ヒドロキシルアミンの存在下では，硝酸 $8 \mathrm{ml}$ までは 水銀測定に影響はなかったが，硝酸量はなるべく少量で あることが望ましいことから残存硝酸量は $5 \mathrm{ml}$ 以下と した.

\section{2. 試料溶液の調製法と検討}

試料の湿式分解において器具からの水銀污染や加熱に よる水銀の揮散が考えられることから，以下のことを調 べた.

(1) ガラス器具からの污染：微量水銀の测定では器具 からの水銀の溶出や污染が測定に影響を与えることも考 えられるので，特に加熱分解に用いる三角フラスコ及び 冷却管は水で薄めた硫酸，硝酸の混液で一度者沸したも のを使用した．酸洗浄した器具を使用して試料分析と同 じ操作を行ったブランク值は $0.025 \mathrm{ppb}$ 未満であり測 定に支障はなかった。

（2）加熱による水銀の揮散：本法では, 硝酸が多く残 ると測定値が低くなる恐れがあるので，ホットプレート の表面温度約 $180^{\circ}$ で 2 時間冷却管をはずして硝酸を気 化させた。この濃縮分解の操作では水銀が揮散する恐れ があるので，共栓付き三角フラスコに $0.01 \mu \mathrm{g} / \mathrm{ml}$ 水銀 標準溶液の 0,0.5, 1.0,3.0,5.0 ml を分取し，水で $20 \mathrm{ml}$ とし, 硝酸 $20 \mathrm{ml}$, 硫酸 $10 \mathrm{ml}$ を加え約 $180^{\circ}$ で 3 時間 加熱濃縮し水銀の揮散を調べた。この濃度範囲では回収 率 90〜 109\%（平均 100\%）で検量線之同様良好な直線 を示した。このことから水銀は $180^{\circ}$ で 3 時間加熱濃縮 した場合でも揮散せず，冷却管は必要ではないことが分
かったしかし，今回の実験では加熱濃縮において激し く反応するためあふれだすことや，突沸する試料あある ので，沸石 2〜3 個を加え，激しく反応する間は冷却管 を使用した。 なお，特に有機物含有量の多いしめじ，バ ナナ，キウィなどは冷却管を取った後，2 時間の加熱濃 縮の途中で硝酸を 2 5 ml 加えると過マンガン酸カリ ウムの消費量も $10 \mathrm{ml}$ で十分であった。

\section{3. 検 墨 線}

$0.01 \mu \mathrm{g} / \mathrm{ml}$ 水銀標準溶液の $0,0.5,1.0,3.0,5.0 \mathrm{ml}$ を, あらかじめ蒸留水約 $50 \mathrm{ml}$ に硫酸 $10 \mathrm{ml}$ を加えたもの に添加し，過マンガン酸カリウムの色が付くまで $5 \%$ 過 マンガン酸カリウムを加えさらに $2 \sim 3$ 滴加えて，水で 約 $80 \mathrm{ml}$ とした，測定の前に過マンガン酸カリウムの色 が消えるまで塩酸ヒドロキシルアミン数滴を加え以下試 料と同様に測定した． $0 \sim 0.8 \mu \mathrm{g}$ の範囲では良好な直線 を示した。

\section{4. 添加回収実験}

白菜, 大根, きゅうり及びりんごに水銀を $0.5 \mathrm{ppb}$ 及 び $2.5 \mathrm{ppb}$ となるように添加した場合の回収率及び変動 係数を Table 1 に示した. $0.5 \mathrm{ppb}$ 添加の場合, 回収率 は, $94 \sim 103 \%$ (平均 99\%)，変動係数は， $2.0 \sim 11 \%$ (平均 5.6\%)，同様に $2.5 \mathrm{ppb}$ 添加の場合， 97 101\% (平均 99\%)，2.8〜 6.3\%（平均 $4.1 \%$ ) であった。 また, 本法の定量下限值は試料 $20 \mathrm{~g}$ を用いた場合 $0.1 \mathrm{ppb}$ で あり，低濃度でも回収率及び精度も良好に測定すること ができた。

\section{5. 野菜及び果物中の総水銀含有量}

市販の野菜 18 種類（サニーレタス, 大根, キャベッ, みずな，白菜，ねぎ，玉ねぎ，ブロッコリ一，かいわれ， きくな, ピーマン，ほうれんそう，みつば，なす，にん じん，しめじ，きゅうり，トマト） 54 検体，いも 3 種類 （さといも，長いも，じゃがいも） 9 検体，果物 6 種類 
Table 2. Total amounts of Mercury in Vegetables and Fruits

\begin{tabular}{|c|c|c|c|c|}
\hline \multirow[b]{3}{*}{ Lettuce } & \multicolumn{4}{|c|}{ Content of total mercury } \\
\hline & \multicolumn{3}{|c|}{ (ppb-Wet weight) } & \multirow{2}{*}{$\frac{\begin{array}{r}\text { Mean } \\
(\mathrm{ppb})\end{array}}{0.2}$} \\
\hline & 0.2 & $<0.1$ & 0.3 & \\
\hline Radish & $<0.1$ & $<0.1$ & $<0.1$ & $<0.1$ \\
\hline Cabbage & 0.2 & $<0.1$ & $<0.1$ & 0.1 \\
\hline Mizuna & 1.9 & 2.9 & 2.6 & 2.4 \\
\hline Chinese cabbage & 0.2 & 0.3 & $<0.1$ & 0.2 \\
\hline Welsh onion & 0.5 & 0.4 & 0.4 & 0.4 \\
\hline Onion & 0.5 & $<0.1$ & $<0.1$ & 0.2 \\
\hline Broccoli & 2.6 & 0.4 & $<0.1$ & 1.0 \\
\hline Kaiware radish & 0.6 & 0.2 & 0.1 & 0.3 \\
\hline Kikuna & 1.2 & 1.2 & 0.6 & 1.0 \\
\hline Sweet pepper & $<0.1$ & $<0.1$ & $<0.1$ & $<0.1$ \\
\hline Spinach & 1.0 & 1.8 & 2.4 & 1.7 \\
\hline Japanese horwort & 0.5 & 0.4 & 0.7 & 0.5 \\
\hline Eggplant & $<0.1$ & $<0.1$ & $<0.1$ & $<0.1$ \\
\hline Carrot & 0.4 & 0.3 & 0.3 & 0.3 \\
\hline Simeji & 1.3 & 2.5 & 1.9 & 1.9 \\
\hline Cucumber & 0.2 & $<0.1$ & $<0.1$ & $<0.1$ \\
\hline Tomato & $<0.1$ & $<0.1$ & $<0.1$ & $<0.1$ \\
\hline Taro & 0.6 & 0.8 & 0.2 & 0.5 \\
\hline Yam & 0.8 & 0.1 & $<0.1$ & 0.3 \\
\hline Potato & $<0.1$ & $<0.1$ & $<0.1$ & $<0.1$ \\
\hline Strawberry & 0.1 & $<0.1$ & $<0.1$ & 0.1 \\
\hline Apple & 0.2 & $<0.1$ & $<0.1$ & 0.1 \\
\hline Kiwi fruit & $<0.1$ & $<0.1$ & $<0.1$ & $<0.1$ \\
\hline Tangerine & $<0.1$ & $<0.1$ & $<0.1$ & $<0.1$ \\
\hline Lemon & $<0.1$ & $<0.1$ & $<0.1$ & $<0.1$ \\
\hline Banana & $<0.1$ & $<0.1$ & $<0.1$ & $<0.1$ \\
\hline
\end{tabular}

(いちご，りんご，キウイ，みかん，レモン，バナナ） 18 検体について測定した結果を Table 2 に示した。 野菜及 び果物 27 種類の中で 10 種類が $0.1 \mathrm{ppb}$ 末満で, 12 種 類が $0.1 \sim 1.0 \mathrm{ppb}$ の範囲にあった. みずな，ブロッコリ 一，きくな，ほうれんそう，しめじの 5 種類が 1.0〜2.4 $\mathrm{ppb}$ と $1 \mathrm{ppb}$ 以上であった. しかし，18 種類の野菜，3 種類のいむ, 6 種類の果物の平均濃度はそれぞれ 0.6 $\mathrm{ppb}, 0.3 \mathrm{ppb}$ 及び $0.1 \mathrm{ppb}$ 末満であった.

昭和 63 年国民栄養調査成績の概要 ${ }^{15)}$ では野菜類 249 $\mathrm{g}$ ，いも類 $66.6 \mathrm{~g}$ ，果実類 $125 \mathrm{~g}$ が一日に摄取されてい ると述べていることから，水銀の一日摂取量は野菜類か ら $0.149 \mu \mathrm{g}$, い屯類から $0.020 \mu \mathrm{g}$ ， 果物類から 0.013 $\mu \mathrm{g}$ 末満, 計 $0.182 \mu \mathrm{g}$ 以下であった. この值は奈良県民 の一日摄取量 ${ }^{16)}$ の $0.9 \%$ 以下にすぎない，また，WHO では 1 週間の搨取量を総水銀として $0.3 \mathrm{mg}$ 以下であれ ば問題の無い量であるとしている ${ }^{17)}$. 喜多村ら ${ }^{18)}$ は水銀 農薬を使用していた昭和 35～36 年の水銀濃度は，りん ごの果肉で $0.06 \sim 0.13 \mathrm{ppm}$, 平均 $0.08 \mathrm{ppm}$, 無散布で
0.01 0.03 ppm，また他の野菜，果物では平均でみかん の果肉 $0.02 \mathrm{ppm}$ ，白菜 $0.03 \mathrm{ppm，ほうれんそう} 0.05$ $\mathrm{ppm}$, にんじん $0.06 \mathrm{ppm}$, 大根 $0.05 \mathrm{ppm}$ であり, 当時 の果実の水銀量は平均的に $0.04 \mathrm{ppm}$ 程度であったと報 告している. また, 水銀農薬の散布中止後の市販農作物 の水銀含量として，根菜類であるじゃがいもは $0.003 〜$ $0.02 \mathrm{ppm}$ (平均 $0.015 \mathrm{ppm}$ )，同様に，さつまいも 0.02 〜0.04 (0.03), さといも 0.003 0.04 (0.02), そ菜類であ る白菜は $0.002 \sim 0.18$ (0.02), 同様にキャベッ $0.002 \sim$ 0.08 (0.02)，ねぎ $0.009 \sim 0.06$ (0.02)，玉ねぎ 0.004 $0.03(0.01)$, 大根 $0.004 \sim 0.14(0.03)$ ，にんじん 0.003 0.08 (0.040), きゅうり $0.002 \sim 0.02(0.01)$, なす 0.004 ,

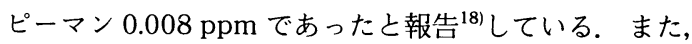

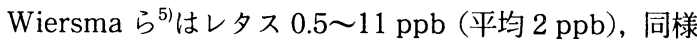
にトマト $0.1 〜 8(1.3)$ きゅうり $0.1 〜 1.5(0.3)$ ，ほうれ んそう 0.1 末満〜29 (5), にんじん 0.6〜 5 (2), じゃがい あ 0.1 末満〜 17 (3), りんご $0.4 〜 3$ (1) ppbであったと 報告している. 本調査での平均值はレタス $0.2 \mathrm{ppb}$, ト マト $0.1 \mathrm{ppb}$ 末満, きゅうり $0.1 \mathrm{ppb}$ 末満, ほうれんそ う $1.7 \mathrm{ppb}$ ，にんじん $0.3 \mathrm{ppb，じゃがいも} 0.1 \mathrm{ppb}$ 未 満, りんご $0.1 \mathrm{ppb}$ 未満であり, 前述の報告值 ${ }^{5)}$. 18) と比 較して，その濃度は水銀農薬の散布中止後の市販農作物 の水銀含量に対し 1 2 桁低く, Wiersma ら ${ }^{5)}$ の報告値 に対しても，ほうれんそうで約 $1 / 3$ ，きゅうりで $1 / 3$ 以 下, レタス,トマト, にんじん, じゃがいも, りんごで は 1 桁低い値であった。

このことから，県内都市部に流通している野菜，果物 中の水銀濃度は，過去に使用した水銀農薬の影響もな く，バックグラウンド值に近い值であると考える.

\section{ま とめ}

1. 本法の水銀の還元気化に影響を及ぼす試薬量につ いて検討したところ，硫酸及び硝酸の影響が大きく，特 に硝酸は塩酸ヒドロキシルアミン $8 \mathrm{ml}$ の存在下では, 硝酸量の増加に伴い吸光度の大きな低下が認められた. $10 \%$ 塩酸ヒドロキシルアミン $8 \mathrm{ml}$ 及び $15 \%$ 過マンガ ン酸カリウム $10 \mathrm{ml}$ の存在下では, 硝酸量 $8 \mathrm{ml}$ までは 水銀測定に影響はなかったが, 残存硝酸量はなるべく少 量であることが望ましかった。

2. 水銀を野菜，果物に対して 0.5 及び $2.5 \mathrm{ppb}$ とな るように添加した場合の回収率及び変動係数は, 0.5 $\mathrm{ppb}$ 添加の場合，回収率は，94〜103\% (平均 99\%), 変 動係数は, $2.0 \sim 11 \%$ (平均 5.6\%), 同様に $2.5 \mathrm{ppb}$ 添加 の場合, $97 \sim 101 \%$ (平均 99\%)，2.8〜6.3\% (平均 4.1\%）であった。 また，定量下限値は試料 $20 \mathrm{~g}$ を用い た場合 $0.1 \mathrm{ppb}$ であり，低濃度でも回収率及び精度も良 好に測定することができた。

3. 多量の生試料を簡単な前処理で迅速に分解し, 試 験溶液の全量を測定に用いるため, $0.1 \mathrm{ppb}$ レベルの低 濃度の試料でも試薬や実験中における污染も少なく，ま 
た，測定に要する時間も短いことから本法は，野菜果物 中の総水銀の分析方法として有用な方法であった。

4. 本法を用いて奈良県下で市販されていた 27 種類 の野菜，果物中の微量水銀について調查したところ，そ の平均値は 10 種類が $0.1 \mathrm{ppb}$ 末満, 12 種類が $0.1 \sim 1.0$ $\mathrm{ppb}, 5$ 種類が 1.0 ～2.4 ppb の範囲にあった.

文献

1) 三島昌夫編：“環境中の微量金属の測定” p. 126 130 (1985) 東京化学同人.

2）並木 博ら編：“詳解 工業排水試験法” p. 459 473 (1987) 日本規格協会(財).

3）森 五郎編：“工業用水試験方法” p. 182～186 (1979) 日 本規格協会.

4）熊谷 洋, 佐伯清子：食衛誌. 17, 200 203 (1976).

5) Wiersma, D., van Goor, B. J., van der Veen, N. G.: J. Agric. Food Chem. 34, 1,067 1,074 (1986).

6) 日本薬学会編：“衛生試験法・注解” p. 52 59, p. 566 567, p. 574 (1990) 金原出版.

7) 厚生省通達：“魚介類の水銀の暫定的規制值について”昭 和 48 年 7 月 23 日 環乳第 99 号 (1973)

8) Deitz, F. D., Sell, J, L., Bristol, D.: J. Assoc. Offic. Anal.
Chem. 56, 378 382 (1973).

9) 白井文雄, 藤田昌彦, 岩島 清：食衛誌. 24, 52 56 (1983).

10）田中之雄, 池辺克彦, 田中凉一, 國田信治: 同上 15, 386 $\sim 389$ (1975).

11）宮永昭一，林 哲生，角 昭美，浅野彦二：同上. 25,30 ３4 (1984)

12）玉瀬喜久雄, 北田善三, 芋生畺子, 蓮池秋一, 佐々木美智 子, 谷川 薫: 同上 $23,388 \sim 392$ (1982).

13）昭和 54 年度環境庁委託業務結果報告書：“日本工業規格 (JIS) の改正に伴う水質測定方法の検討試験” 全国公害研 協議会 p. 133～140 (1980).

14) 内野栄治, 小西繁樹, 西村雅吉：分析化学 27, 457 459 (1978).

15）厚生省保健医療局健康増進栄養課：“国民栄養の現状（昭 和 63 年国民栄養調查成績)” p. 152 (1990).

16）田中 健, 岡田 作, 市村國俊, 西川喜孝：奈良県衛生研 究所報. 21, 50 53 (1986).

17) WHO Technical Report Series No. 532, p. 48 49, WHO, Geneva (1973).

18）喜田村正次, 近藤雅臣, 瀧澤行雄, 藤井正美, 藤木素士編： “水銀” p. 142２07 (1976) 講談社. 